\title{
Microstructures and interlayering in pyrophyllite from the Coastal Range of central Chile: evidence of a disequilibrium assemblage
}

\author{
M. D. Ruiz Cruz ${ }^{1} *$, D. Morata ${ }^{2}$, E. Puga ${ }^{3}$, L. Aguirre $^{2}$ and M. Vergara ${ }^{2}$ \\ ${ }^{1}$ Departamento de Química Inorgánica, Cristalografia y Mineralogía, Facultad de Ciencias, Universidad de Málaga, \\ 29071 Málaga, Spain, ${ }^{2}$ Departamento de Geología, Universidad de Chile, Plaza Ercilla, 803, Santiago, Chile, and \\ ${ }^{3}$ Instituto Andaluz de Ciencias de la Tierra (C.S.I.C.-U.G.R.), Avda. Fuentenueva s/n, 18002 Granada, Spain
}

(Received 5 December 2003; revised 19 April 2004)

\begin{abstract}
Pyrophyllite from a Triassic sedimentary formation from the Coastal Range of Chile has been investigated by transmission/analytical electron microscopy (TEM/AEM). The mineral assemblage includes pyrophyllite, muscovite, paragonite, a kaolin mineral, boehmite, rutile and hematite. The textures indicate that the protolith was a volcanoclastic rock. Petrographic evidence, chemistry, and the mineral assemblage suggest the intense leaching of the parent rock by a weathering process, before the metamorphic episode, to create the protolith for the pyrophyllite. Pyrophyllite always grows from the kaolin mineral, and both phases show close orientation relationships. The presence of parallel intergrowths of pyrophyllite and muscovite indicate that muscovite also grew from the kaolin mineral. Nevertheless, the composition of muscovite suggests that this phase must also form from another precursor, probably Al smectite. The AEM data and textural relationships between pyrophyllite and muscovite reveal the presence of two generations of muscovite and suggest that Na-rich muscovite recrystallized into a Na-free muscovite and paragonite.
\end{abstract}

Keywords: analytical electron microscopy, Andes, Chile, dickite, muscovite, metaclastite, pyrophyllite, structural defects, transmission electron microscopy.

Pyrophyllite, once thought rare, is a low-grade metamorphic mineral typically formed in Al-rich rocks, such as highly aluminous metapelites, metabauxites, aluminous metaquartzites, and hydrothermally altered acidic and intermediate silicate rocks (e.g. Zen, 1961; Robert, 1971; Jansen \& Schuiling, 1976; Frey, 1978, 1987; Sharma, 1979; Evans \& Guggenheim, 1991). Depending on $T, P$ and fluid properties, pyrophyllite can be accompanied in these occurrences by a variety of

*E-mail: mdruiz@uma.es

DOI: $10.1180 / 0009855043940146$ minerals, such as quartz, mica, kaolin minerals (kaolinite and/or dickite), sudoite, cookeite, diaspore, andalusite, topaz, etc.

In the system $\mathrm{Al}_{2} \mathrm{O}_{3}-\mathrm{SiO}_{2}-\mathrm{H}_{2} \mathrm{O}$ (Evans \& Guggenheim, 1991) pyrophyllite is stable over a narrow temperature range $\left(\sim 250\right.$ to $\left.\sim 350^{\circ} \mathrm{C}\right)$, with the most frequent reactions producing pyrophyllite during prograde metamorphism being:

$$
\begin{aligned}
& \mathrm{Kln}+2 \mathrm{Qtz}=\mathrm{Prl}+\mathrm{H}_{2} \mathrm{O}, \text { and } \\
& 2 \mathrm{~K} l n=\mathrm{Prl}+2 \mathrm{Dsp}+2 \mathrm{H}_{2} \mathrm{O}
\end{aligned}
$$

More complex systems explain the relation between pyrophyllite and numerous other minerals (e.g. Montoya \& Hemley, 1975; Bowers et al., 1984). 
In some pyrophyllite occurrences, the presence of regularly or randomly interstratified phases, consisting of the alternation of pyrophyllite layers and smectite, kaolinite or mica layers has been described (e.g. Kodama, 1958; Page, 1980). The presence of complete or partial interlayering of one phyllosilicate with another phyllosilicate has often been used to determine the origin and the mechanisms of transformation between the phases (e.g. Reynolds, 1991; Merriman \& Peacor, 1999, and references therein).

Triassic Si-rich low-grade metaclastites from the Coastal Range of central Chile are characterized by the assemblage quartz + albite + mica \pm chlorite, occasionally coexisting with chlorite-bearing mixedlayers (Ruiz Cruz et al., 2002). Nevertheless, some Triassic sedimentary beds show 'anomalous' assemblages, being enriched in muscovite, chlorite or pyrophyllite. This local argillic enrichment suggests either hydrothermal alteration of the rocks or initial protoliths with 'anomalous' chemical and mineralogical compositions. One of these beds contains significant amounts of pyrophyllite, as well as minor mica, a kaolin-mineral (probably dickite), boehmite and Fe oxides. The study by TEM/AEM has allowed the identification of microstructures in pyrophyllite as well as the detailed study of the textural relations among pyrophyllite and the other mineral phases. The origin of this mineral assemblage and the implications with regard to the conditions of formation are considered in the present paper.

\section{GEOLOGICAL SETTING AND PETROGRAPHY}

The genesis of the Coastal Range in central Chile is the consequence of phenomena related to magmatism (plutonism and volcanism), basin formation, subsidence inversion and final exhumation in an active continental margin during the Mesozoic. Along this margin, the continental crust went through recurrent periods of extension and compression, mainly as the consequence of a continuous convergence of oceanic and continental plates. These changeable geodynamic settings would have determined the nature of the magmatic products generated during the Mesozoic as well as the pattern of the very low-grade, non-deformational, metamorphism related to them. A regional, and of predominantly burial character, low-grade (subgreenschist to low greenschist-facies) metamorphism is widely developed in all Mesozoic rocks (e.g. Levi et al., 1989; Robinson et al., 2004), the Triassic rocks being mostly metamorphosed in the prehnite-pumpellyite facies (Levi et al., 1989).

Exposures of Triassic rock in central Chile are poor and scattered (Charrier, 1979; Aguirre, 1985). At $\sim 32^{\circ}$ Lat. S, these Triassic units correspond to El Quereo, Pichidangui and Los Molles Formations (all of them located at the coastline) and the La Ligua Formation (Fig. 1). The latter (defined by Thomas, 1958) consists of more than $800 \mathrm{~m}$ of slightly folded, stratified altered silicic lava flows, breccias and tuffs

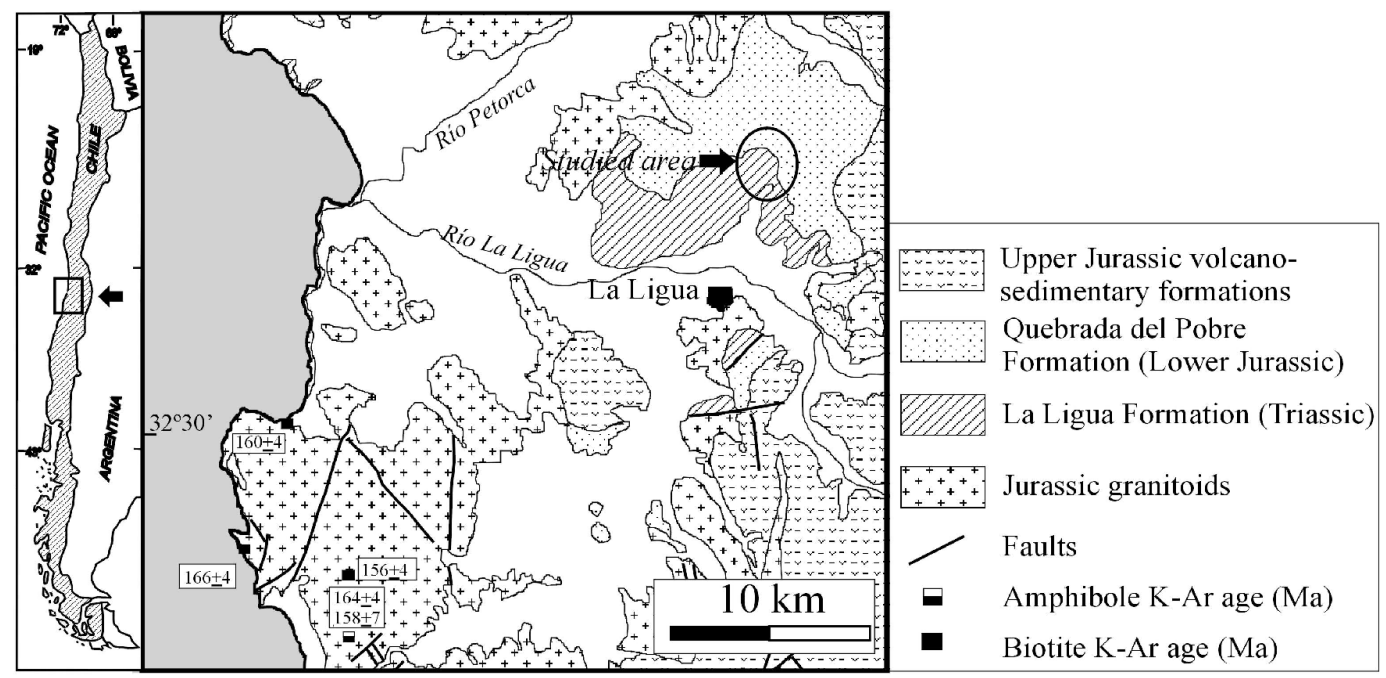

Fig. 1. Simplified geological map of the Coastal Range of central Chile at $\sim 32^{\circ} \mathrm{S}$ with location of the studied samples (simplified from Rivano et al., 1993). 
intercalated with shales, quartz-rich sandstones, and scarce conglomerates, affected by non-deformative, very low-grade metamorphism. This formation is overlain by the Quebrada del Pobre Formation (Thomas, 1958), a $1250 \mathrm{~m}$ thick, marine clastic sedimentary (sublittoral to littoral) unit composed of greenish grey quartzo-feldspathic sandstones and fine conglomerates with dark grey silstones and silty limestone layers. The formation contains an Early Jurassic (Sinemurian) fossil fauna (Vergara et al., 1995). These formations were intruded by Jurassic granodiorites and tonalites (biotite and amphibole KAr ages of $164 \pm 4$ to $158 \pm 7 \mathrm{Ma}$ ) belonging to the Cavilolén Unit (Rivano et al., 1993). Previous work on very low-grade metamorphism by Oyarzun et al. (1997) on volcanic rocks from the Pichidangui Formation, indicating metamorphic parageneses indicative of the transition between pumpellyiteactinolite, prehnite-actinolite and greenschist metamorphic facies. Ruiz-Cruz et al. (2002) identified mica-chlorite and chlorite-vermiculite mixed layers as metastable structures in low-grade metasediments from the El Quereo Formation.

Triassic metaclastites from the La Ligua formation include metagreywackes and metapelites, characterized by the assemblage quartz + muscovite \pm chlorite \pm feldspar \pm Fe oxides \pm carbonates, feldspar being relatively scarce. The metagreywackes comprise well rounded, elongated, detrital grains (between 0.5 and $1.6 \mathrm{~mm}$ in diameter), including quartz, fragments of metamorphic and volcanic rocks, opaque oxides, illitized feldspar, and large mica flakes, in a very abundant micaceous matrix. Metapelites show a beddingparallel fabric, mainly marked by the alternation of oxide- and mica-rich beds. This initial fabric appears slightly deformed by an incipient slate cleavage, which causes crenulation and recrystallization of quartz and white mica.

The pyrophyllite bed shows textural and mineralogical characteristics different from the metaclastites. Quartz is absent and pyrophyllite and mica form thin flakes in the order of $20 \mu \mathrm{m}$ in size. Relics of 'flame' textures indicate that this bed has essentially a volcanoclastic origin.

\section{METHODOLOGY}

Triassic metaclastites were studied by optical microscopy, X-ray diffraction (XRD) methods and X-ray fluorescence (XRF). The XRD patterns were recorded using a Siemens-5000 diffractometer (at
Málaga University), with $\mathrm{Cu}-K \alpha$ radiation and a graphite monochromator, operated at $40 \mathrm{~mA}$ and $40 \mathrm{kV}, 0.01^{\circ}$ step size and $1 \mathrm{~s}$ counting time. Bulkrock mineralogy was determined from unoriented patterns and semiquantitative determinations used the intensity factors of Schultz (1964). Several sizefractions separated by sedimentation and/or centrifugation were used for phyllosilicate identification. The XRD patterns were obtained from oriented samples in the air-dried state, after ethylene glycol solvation, and after heating at $550^{\circ} \mathrm{C}$.

Samples prepared as fused glass were analysed using a Philips PW 1040/10 XRF spectrometer (C.I.C., Granada University). Rock powder was combined with lithium tetraborate flux after the method described by Norrish \& Hutton (1969) and glass beads were employed to minimize the preferential orientation of phyllosilicates. The detection limit for the major elements is 0.01 wt.\%. The loss on ignition (LOI) was determined separately from $0.5 \mathrm{~g}$ of powdered sample, first dried at $110^{\circ} \mathrm{C}$ and then heated at $1000^{\circ} \mathrm{C}$ for $1 \mathrm{~h}$. Total iron is reported as ferric.

The pyrophyllite bed was also studied by TEM/ AEM. Thin sections were prepared with orientation perpendicular to the bedding. Washers were attached to selected areas and later separated from the glass backing. These areas were ion-thinned and carbon coated and examined in a $200 \mathrm{kV}$ Philips CM-20 transmission electron microscope (C.I.C., Granada University), fitted with a solid-state detector for energy dispersive analysis (EDX). Lattice-fringe images were obtained using $00 l$ reflections and underfocus conditions corresponding to maximum contrast. Chemical analyses were obtained in the STEM mode for areas that were first characterized by electron diffraction and lattice-fringe imaging. Muscovite, albite, spessartine, forsterite and titanite were used as standards to calculate K-factors by the thin-film method of Lorimer \& Cliff (1976).

\section{RESULTS}

The chemical composition of the pyrophyllite bed (CHE-149), one metapelite (CHE-148) and one metagreywacke (CHE-150) are reported in Table 1. The mineral composition of these samples, deduced from the optical study and the XRD patterns is shown in Table 2.

The chemical composition of the pyrophyllite bed shows, as expected from its mineralogical composi- 
TABLE 1. Major-element (XRF), whole-rock chemical composition (wt.\%) of the Triassic rocks from La Ligua (Coastal Range of central Chile). Location of samples in Fig. 1.

\begin{tabular}{lccc}
\hline Oxides & $\begin{array}{c}\text { CHE-148 } \\
\text { (metapelite) }\end{array}$ & $\begin{array}{c}\text { CHE-149 } \\
\text { (pyrophyllite bed) }\end{array}$ & $\begin{array}{c}\text { CHE-150 } \\
\text { (metagreywacke) }\end{array}$ \\
\hline $\mathrm{SiO}_{2}$ & 53.05 & 45.40 & 58.06 \\
$\mathrm{Al}_{2} \mathrm{O}_{3}$ & 21.80 & 28.19 & 23.89 \\
$\mathrm{Fe}_{2} \mathrm{O}_{3}{ }^{*}$ & 13.36 & 13.08 & 5.53 \\
$\mathrm{MnO}$ & 0.01 & 0.00 & 0.01 \\
$\mathrm{MgO}$ & 0.18 & 0.03 & 0.14 \\
$\mathrm{CaO}$ & 0.07 & 0.40 & 0.04 \\
$\mathrm{Na}$ & 0.33 & 0.41 & 0.50 \\
$\mathrm{~K}_{2} \mathrm{O}$ & 5.27 & 0.41 & 5.81 \\
$\mathrm{TiO}_{2}$ & 2.84 & 3.37 & 2.07 \\
$\mathrm{P}_{2} \mathrm{O}_{5}$ & 0.06 & 0.49 & 0.06 \\
$\mathrm{H}_{2} \mathrm{O}^{* *}$ & 3.59 & 6.50 & 3.78 \\
$\mathrm{Total}$ & 100.56 & 99.62 & 99.89 \\
& & & \\
\hline
\end{tabular}

* $\mathrm{Fe}_{2} \mathrm{O}_{3}$ as total iron. ${ }^{*} \mathrm{H}_{2} \mathrm{O}$ by LOI

tion, lower $\mathrm{SiO}_{2}$ and higher $\mathrm{Al}_{2} \mathrm{O}_{3}$ contents than the associated metaclastites. It also shows very small amounts of $\mathrm{MgO}, \mathrm{CaO}, \mathrm{Na}_{2} \mathrm{O}$ and $\mathrm{K}_{2} \mathrm{O}$, and a relatively large amount of $\mathrm{TiO}_{2}$. The chemical composition is, thus, clearly different from the common metaclastites from this formation, and reflects its different initial composition and an intense leaching process, which presumably occurred prior to the metamorphic one. The plot of the chemical composition of the studied rocks, in a $\mathrm{SiO}_{2}-\mathrm{Al}_{2} \mathrm{O}_{3}-\mathrm{H}_{2} \mathrm{O}$ triangular diagram is shown in Fig. 2.
The XRD patterns of the pyrophyllite bed (Fig. 3) are dominated by the pyrophyllite reflections, also including muscovite, kaolin minerals, boehmite, hematite and rutile reflections. A diffuse reflection at $\sim 4.15 \AA$ suggests the presence of a small amount of opal C-T. The muscovite basal reflections are sharp and the Kübler index $(\mathrm{KI})$ is $0.26\left(\Delta^{\mathrm{o}} 2 \theta\right)$. The small muscovite content prevents the accurate identification of the polytype by means of XRD. A small peak present at $\sim 9.5 \AA$ corresponds to paragonite. The half-height width of the first basal reflection of pyrophyllite is $0.30\left(\Delta^{\circ} 2 \theta\right)$. On the

TABLE 2. Mineral composition of the Triassic rocks from La Ligua formation, including the pyrophyllite-bearing bed.

\begin{tabular}{lccc}
\hline Minerals & $\begin{array}{c}\text { CHE-148 } \\
\text { (metapelite) }\end{array}$ & $\begin{array}{c}\text { CHE-149 } \\
\text { (pyrophyllite bed) }\end{array}$ & $\begin{array}{c}\text { CHE-150 } \\
\text { (metagreywacke) }\end{array}$ \\
\hline Quartz & $\mathrm{xxx}$ & - & $\mathrm{xxxx}$ \\
Feldspar & $\mathrm{xx}$ & - & $\mathrm{x}$ \\
Mica & $\mathrm{xxxx}$ & $\mathrm{xx}$ & $\mathrm{xxx}$ \\
Kaolin & - & $\mathrm{x}$ & - \\
Pyrophyllite & - & - & - \\
Chlorite & - & $\mathrm{x}$ & $\mathrm{x}$ \\
Boehmite & - & $\mathrm{xxx}$ & - \\
Hematite & $\mathrm{xxx}$ & $\mathrm{x}$ & - \\
Rutile & - & - & $(\mathrm{x})$ \\
Carbonate & $(\mathrm{x})$ & & \\
\hline
\end{tabular}

xxxx: $>50 \%$; xxx: $10-50 \%$; xx: $5-10 \%$; $:<5 \%$; $(\mathrm{x})$ : trace; - not detected 


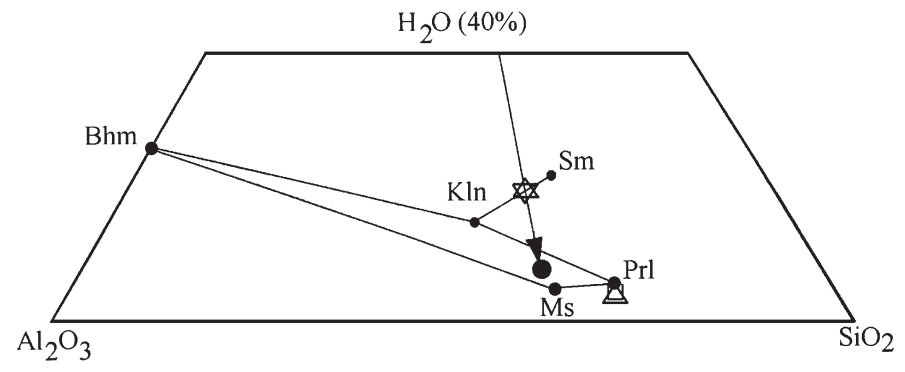

FIG. 2. Plot of the bulk composition of the Triassic rocks on an $\mathrm{SiO}_{2}-\mathrm{Al}_{2} \mathrm{O}_{3}-\mathrm{H}_{2} \mathrm{O}$ triangular diagram. Filled circle: pyrophyllitic bed (sample CHE-149); open triangle: metagreywacke (sample CHE-150); open square: metapelite (sample CHE-148); star: probable composition of the protolith. The composition of smectite (Sm) corresponds to mean values of beidellite analyses taken from Deer et al. (1975b). The arrow indicates the probable evolution of the bulk rock composition during the metamorphic process. Prl: pyrophyllite; Ms: muscovite; Bhm: boehmite;

Kln: kaolin mineral (according to Kretz, 1983). These symbols are also used in the following figures.

contrary, the basal reflections of the kaolin mineral are broad, suggesting either important structural disorder or the presence of some mixed-layer structures. The low intensity of the kaolin mineral reflections also prevents the identification of the polytype by means of XRD. Treatment of the sample with ethylene glycol, and heating at $550^{\circ} \mathrm{C}$ do not modify the shape or the position of the basal reflections of the several phyllosilicates, indicating the absence of smectite interlayering. The XRD

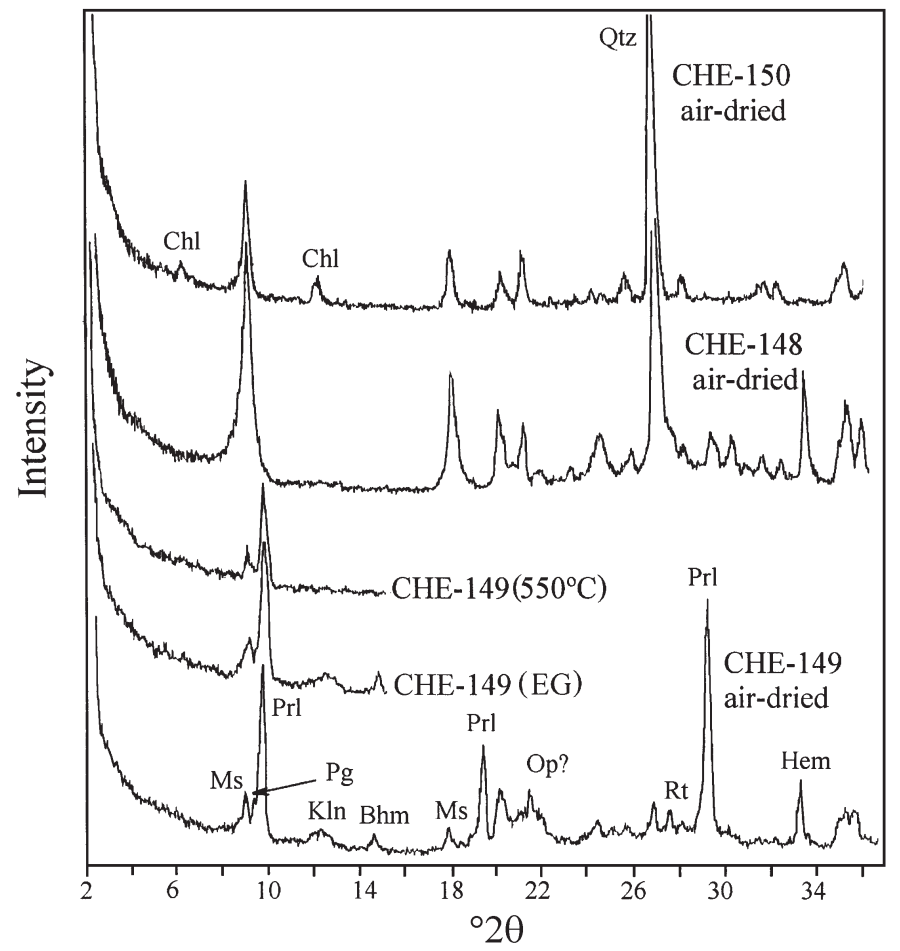

FIG. 3. XRD patterns of samples CHE-148 (air-dried), CHE-150 (air-dried) and CHE-149 (air-dried, after ethylene-glycol treatment and after heating at $550^{\circ} \mathrm{C}$ ). The main reflections of pyrophyllite, muscovite, a kaolin mineral, boehmite, hematite $(\mathrm{Hem})$ and rutile $(\mathrm{Rt})$, have been labelled. The arrow marks the $9.5 \AA$ reflection, which corresponds to paragonite (Pg). Op: opal C-T. 
patterns of the other Triassic metaclastites (Fig. 3) indicate $\mathrm{KI}$ values between 0.35 and $0.40(\Delta 2 \theta)$, as well as the absence of smectite- or chlorite-bearing mixed layers.

\section{TEM/AEM STUDY}

Low-magnification TEM observation of sample CHE-149 reveals the presence of complex intergrowths among pyrophyllite and the other coexisting minerals, some of which are shown in Fig. 4. Pyrophyllite appears frequently as large, undeformed packets, with thickness up to $0.5 \mu \mathrm{m}$, which occasionally form parallel growths with muscovite. The large packets are often limited by a kaolin mineral at one side and boehmite at the other (Fig. 4a); the boundary between pyrophyllite and the kaolin mineral is coherent, whereas
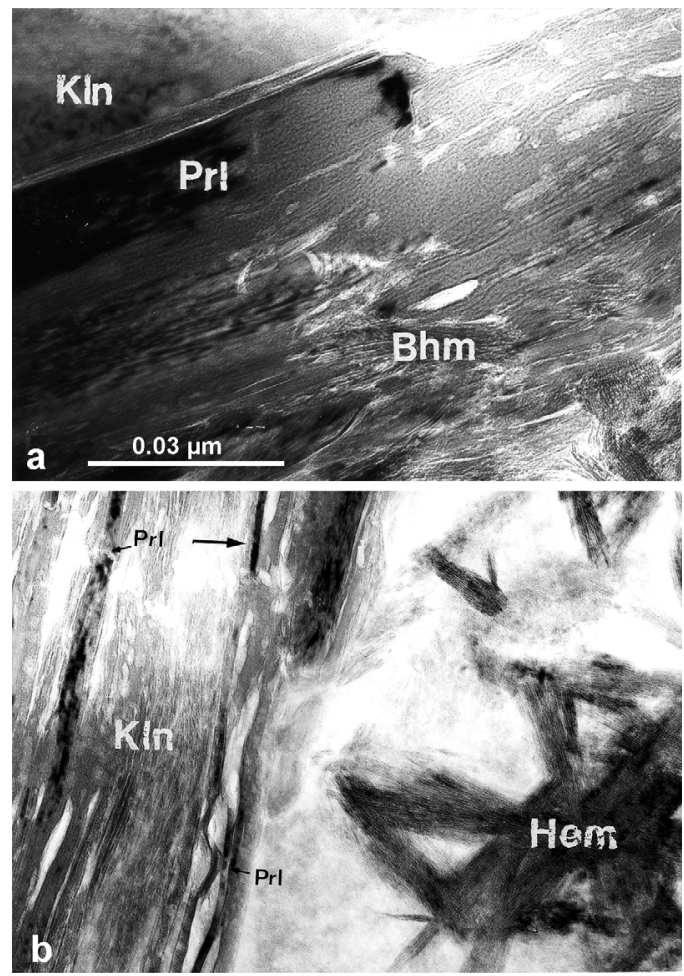

FIG. 4. Low-magnification images showing some textural relations observed among the minerals forming the pyrophyllitic rock. (a) Textural relationships between pyrophyllite, a kaolin mineral and boehmite. (b) Fine intergrowth of a kaolin mineral and pyrophyllite. Hematite forms star-like aggregates. The scale is the same for the two images. pyrophyllite and boehmite form complex intergrowths with incoherent, oblique boundaries. Thinner pyrophyllite packets (on the order of 50-100 $\AA$ ) are also frequent, mainly intergrown with the kaolin mineral (Fig. 4b) or forming islands within the kaolin mineral packets. The Fe oxides (hematite) appear either as star-like aggregates of lath-shaped particles (Fig. 4b) or as rounded inclusions in boehmite. Rutile inclusions are also frequent.

The high-resolution images of the large packets of pyrophyllite show high structural regularity, although they frequently appear damaged by the effect of the electron beam (Fig. 5). This image shows sequences of layers with regular basal spacing of $\sim 9 \AA$, although locally, sequences with two-layer periodicity contrast $(\sim 18 \AA)$ are also observed, suggesting the presence of mixtures of one-layer and two-layer polytypes. Nevertheless, the SAED patterns obtained in these areas (inset in Fig. 5) show pyrophyllite reflections that correspond to a one-layer, triclinic polytype (Bailey, 1984; Evans \& Guggenheim, 1991). The AEM data of these packets (Table 3) indicate little or no tetrahedral $\mathrm{Al}$ and very small Fe contents. Structural defects are scarce in these packets, but the presence of twinning can be occasionally observed in the two-dimensional high-resolution images obtained along the [110] (Fig. 6). This image reveals that the $18 \AA$ fringes or sequences of fringes really correspond to a two-layer polytype, the two-layer and one-layer areas are frequently limited by twin planes. In these areas the SAED patterns show streaking parallel to $c^{*}$ in the $h h l$ reflection rows with $k \neq 3 n$.

Structural defects such as stacking disorder, layer terminations, and several types of interstratifications are more frequent at the boundaries between pyrophyllite and other phases, and mainly in the thin packets intergrown with the kaolin mineral. Figure 7 shows an example of these types of microstructures, near the boundary between pyrophyllite and muscovite. In this case, fringes or groups of fringes with spacing of $10 \AA$, irregularly spaced, are visible within the pyrophyllite packet. This image also shows the transition of one $10 \AA$ layer to one or two $9 \AA$ layers, which leads to bending of the nearest layers of pyrophyllite. Contrast effects indicate significant strain. Similar images were reported by Page (1980). The SAED pattern (inset in Fig. 7) shows well defined basal reflections of both muscovite and pyrophyllite, 


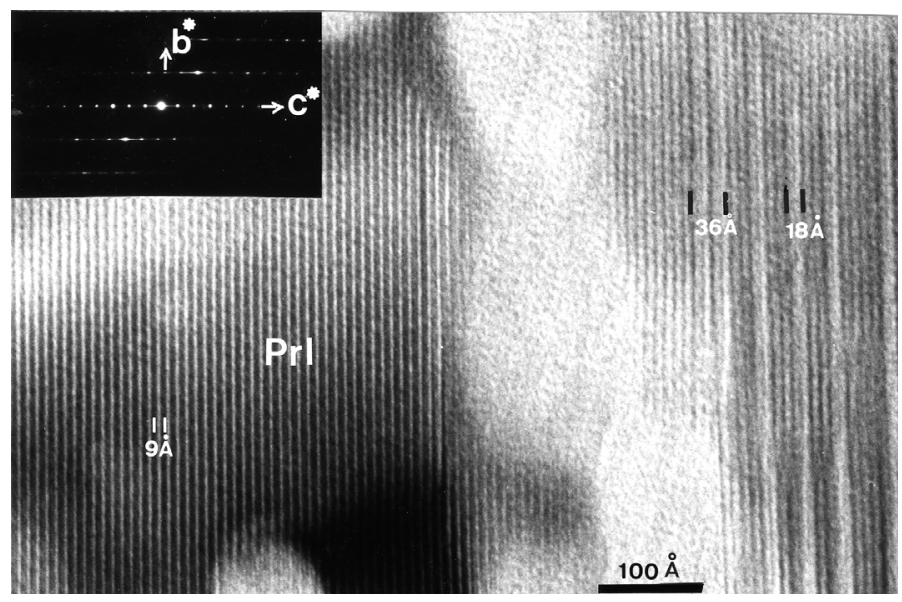

FIG. 5. Lattice-fringe image of a large packet of pyrophyllite, showing fringes with $9 \AA$ and $18 \AA$ periodicities. Pyrophyllite appears damaged by interaction with the electron beam. The SAED pattern, obtained along [100], shows the basal spacing of pyrophyllite and the presence of a one-layer polytype.

whereas the non-basal reflections with $k \neq 3 n$ reflect the structural disorder. The AEM data obtained in these packets and in the adjacent mica packet are reported in Table 3. The low Si content, the high $\mathrm{Al}$ content and the presence of $\mathrm{K}$ in the analyses obtained in the pyrophyllite packet clearly indicate that the $10 \AA$ fringes correspond to muscovite. In these areas, muscovite analyses show a high proportion of $\mathrm{Na}$ but neither the high-resolution images nor the SAED patterns indicate the presence of mixed-layer muscovite/ paragonite. These data suggest that this material was a metastable phase, similar to that described by Jiang et al. (1990), containing either variable

TABLE 3. AEM data for the mineral shown in the Figs 5-11.

\begin{tabular}{|c|c|c|c|c|c|c|c|c|c|c|c|c|c|c|}
\hline & \multirow{2}{*}{$\begin{array}{c}\text { Fig. } 5 \\
\text { Prl }\end{array}$} & \multirow{2}{*}{$\begin{array}{c}\text { Fig. } 6 \\
\text { Prl }\end{array}$} & \multicolumn{2}{|c|}{ Fig. 7} & \multicolumn{2}{|c|}{ Fig. 8} & \multicolumn{2}{|c|}{ Fig. 9} & \multirow{2}{*}{$\begin{array}{l}\text { Fig. } 10 \\
\mathrm{Prl} / \mathrm{K} l n\end{array}$} & \multicolumn{2}{|c|}{ Fig. 11a } & \multicolumn{3}{|c|}{ Fig. 11b } \\
\hline & & & $\operatorname{Prl} / \mathrm{Ms}$ & Ms & $\mathrm{Prl} / \mathrm{K} \ln$ & $\mathrm{K} \ln$ & Prl & $\mathrm{Prl} / \mathrm{K} \ln$ & & $\operatorname{Prl}$ & Ms & Prl & Ms & Ms \\
\hline $\mathrm{Si}$ & 64.63 & 66.33 & 56.17 & 45.11 & 55.25 & 49.79 & 66.08 & 59.14 & 54.83 & 63.59 & 45.62 & 63.91 & 45.14 & 42.55 \\
\hline $\mathrm{Al}$ & 34.59 & 32.79 & 38.68 & 41.55 & 43.48 & 44.41 & 33.92 & 39.66 & 43.24 & 34.29 & 41.74 & 31.17 & 42.22 & 41.73 \\
\hline $\mathrm{Fe}$ & 0.70 & 0.87 & 1.52 & 1.19 & 1.27 & 2.87 & - & 1.21 & 1.22 & 1.24 & 1.80 & 0.50 & 1.19 & 2.26 \\
\hline $\mathrm{Mg}$ & - & - & - & 0.88 & - & - & - & - & - & 0.88 & - & - & - & - \\
\hline $\mathrm{Mn}$ & 0.10 & - & - & - & - & - & & & & & & & & \\
\hline $\mathrm{Na}$ & - & - & - & 4.32 & - & - & - & - & - & - & 2.32 & - & - & - \\
\hline K & - & - & 3.63 & 6.95 & - & 0.86 & - & - & 0.65 & - & 8.52 & 0.42 & 11.45 & 13.43 \\
\hline \multicolumn{15}{|c|}{ Structural formulae } \\
\hline${ }^{\mathrm{IV}} \mathrm{Si}$ & 3.90 & 3.99 & & 3.10 & & 1.95 & 3.97 & & & 3.85 & 3.10 & 3.88 & 3.10 & 2.98 \\
\hline${ }^{\mathrm{IV}} \mathrm{Al}$ & 0.10 & 0.01 & & 0.90 & & 0.05 & 0.03 & & & 0.15 & 0.90 & 0.12 & 0.90 & 1.02 \\
\hline${ }^{\mathrm{VI}} \mathrm{Al}$ & 1.99 & 1.96 & & 1.96 & & 1.90 & 2.01 & & & 1.92 & 1.94 & 2.01 & 2.00 & 1.91 \\
\hline $\mathrm{Fe}$ & 0.04 & 0.05 & & 0.08 & & 0.12 & - & & & 0.07 & 0.12 & 0.03 & 0.08 & 0.16 \\
\hline $\mathrm{Mg}$ & - & - & & 0.06 & & - & - & & & 0.05 & - & - & - & - \\
\hline $\mathrm{Mn}$ & 0.01 & - & & - & & - & & & & & & & & \\
\hline $\mathrm{Na}$ & - & - & & 0.28 & & - & - & & & - & 0.16 & - & - & - \\
\hline K & - & - & & 0.42 & & 0.03 & - & & & - & 0.58 & 0.02 & 0.79 & 0.94 \\
\hline $\mathrm{O}$ & 11 & 11 & & 11 & & 7 & 11 & & & 11 & 11 & 11 & 11 & 11 \\
\hline
\end{tabular}




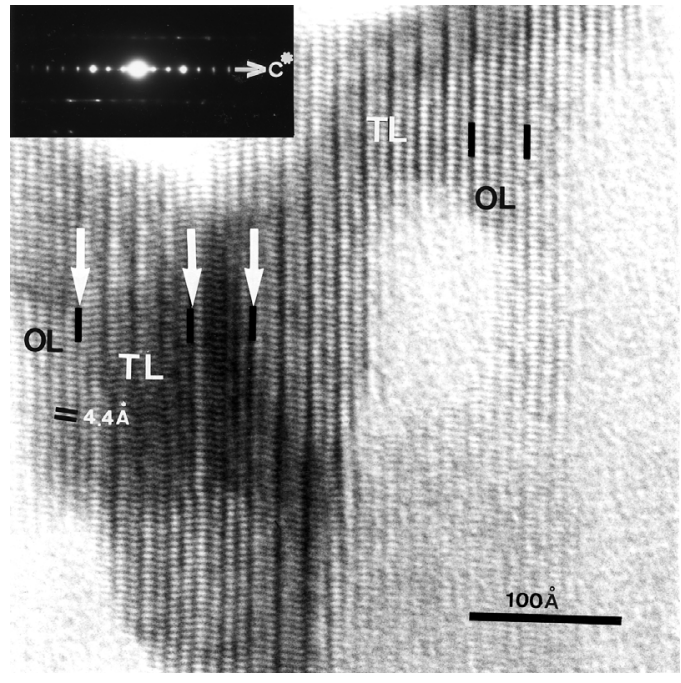

FIG. 6. Lattice-fringe image obtained along [110], showing the presence of twinned lamellae (arrow) consisting of one-layer (OL) and two-layer (TL) polytypes of pyrophyllite.

amounts of $\mathrm{Na}$ and $\mathrm{K}$ within the individual layers or having Na- and K-rich layers randomly interleaved. Such a phase is probably the precursor of $\mathrm{Na}$ - and $\mathrm{K}$-rich end-members.
Figures 8, 9 and 10 show some of the microstructures observed near the boundary between pyrophyllite and the kaolin mineral. In Fig. 8, the pyrophyllite packet contains regularly spaced $14 \AA$ fringes, which can be interpreted, on the basis of the AEM data, as due either to two kaolinite layers or to one dickite layer. Although the rapid damage of the kaolin mineral prevents obtaining bidimensional SAED patterns appropriate for the unambiguous characterization of the kaolin polytype, the fact that the thickness of the interstratified phase is always an even multiple of 7, suggests that they are true dickite layers. The AEM data of the packet shown in Fig. 8 and of the adjacent kaolin mineral packet are shown in Table 3. The analysis of the mixed-layer packet is intermediate between that of pyrophyllite and the kaolin mineral. The kaolin mineral analyses show relatively large Fe contents, which must occupy the octahedral positions, since Fe oxide inclusions have not been observed by TEM.

Fringes with large spacings are also observed in Fig. 9, again at the boundary between a pyrophyllite and a kaolin mineral packet. These fringes, with very variable thickness probably represent randomly ordered interstratifications of pyrophyllite and dickite. Again the AEM data of this type of packet are intermediate between pyrophyllite and

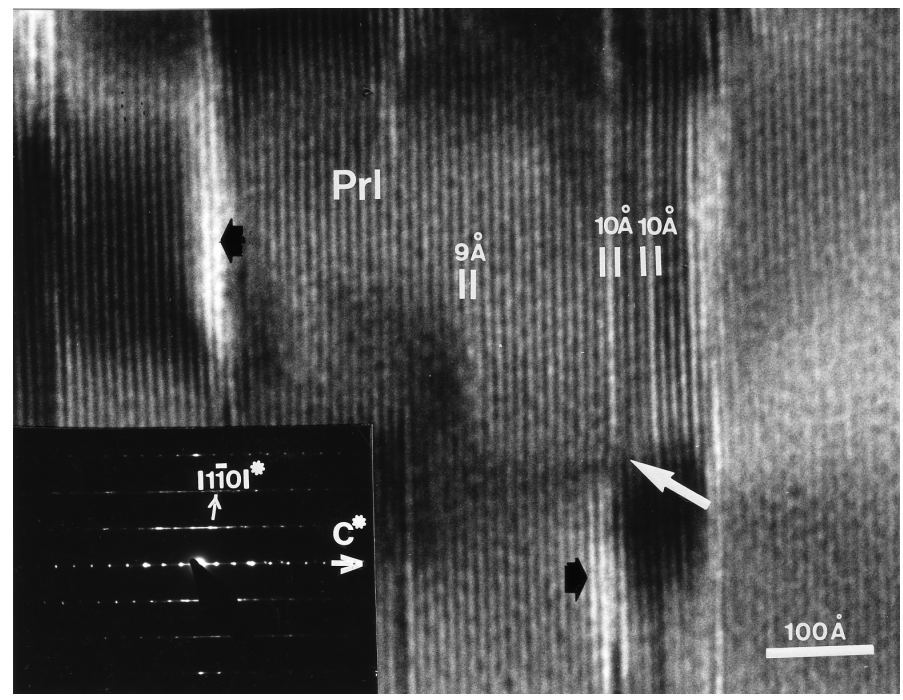

FIG. 7. Lattice-fringe image of a pyrophyllite packet, obtained near the boundary with a muscovite packet. Partial and complete $10 \AA$ fringes or groups of fringes appear irregularly spaced within the pyrophyllite packet. Partial interlayering (black arrows) and layer termination (white arrow) cause contrast strain. The SAED pattern (inset) obtained along $[1 \overline{1} 0]$ of pyrophyllite and muscovite, shows the reflections of both phases and the close orientation relationships. 


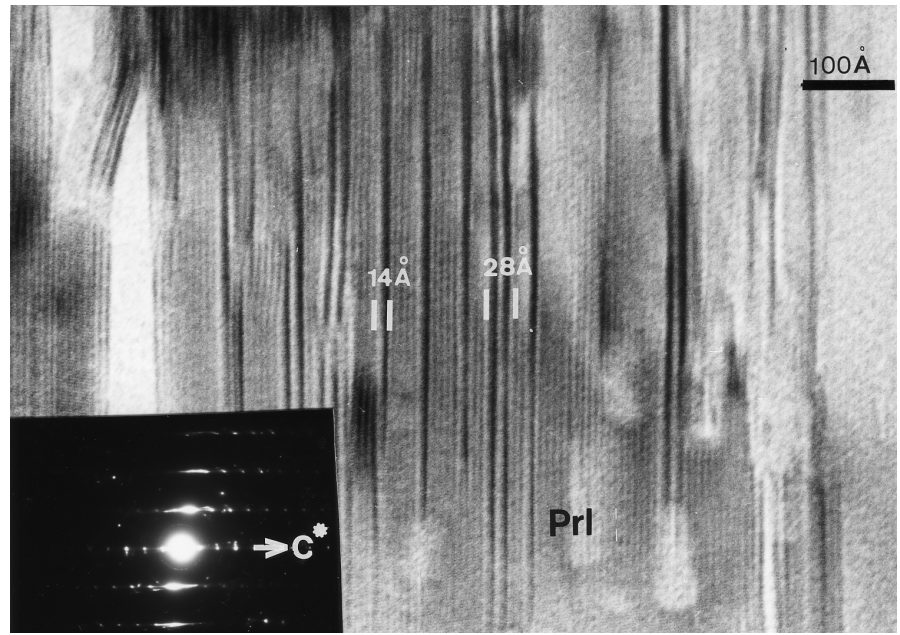

FIG. 8. Lattice-fringe image obtained near the boundary between pyrophyllite and the kaolin mineral, showing $14 \AA$ fringes or groups of fringes, interpreted as dickite layers, almost regularly spaced within the pyrophyllite packet. The SAED pattern (inset) only shows the pyrophyllite reflections.

a kaolin mineral (Table 3). Pyrophyllite islands within the kaolin mineral packets are also observed locally (Fig. 10). The $9 \AA$ packet also contains $14 \AA$ or $28 \AA$ fringes of dickite. These layers or groups of layers of pyrophyllite are, in some cases, too thin to produce diffraction effects. Nevertheless,
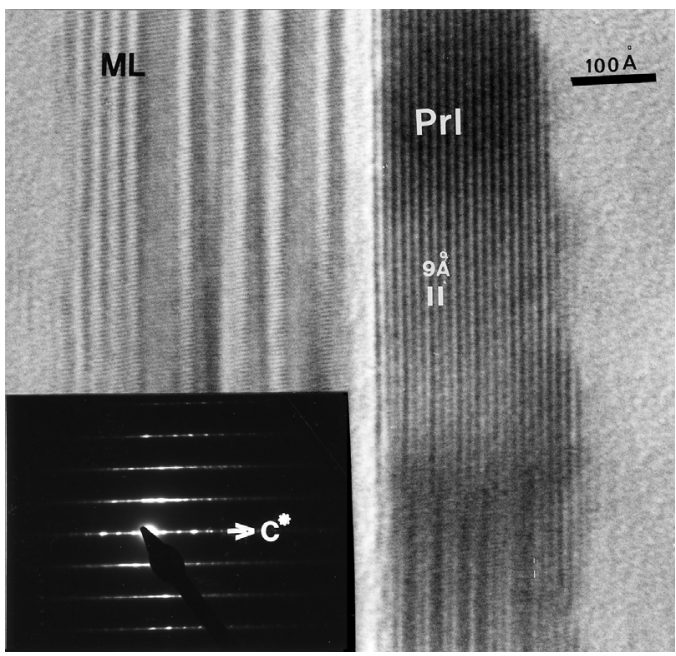

FIG. 9. High-resolution image showing complex interstratifications (ML) at the proximity of the boundary pyrophyllite-kaolin mineral. The SAED pattern, obtained along [001] shows the reflections of both phases. The series of reflections observed in the $h h l$ reflection rows suggest the presence of a two-layer kaolin mineral.

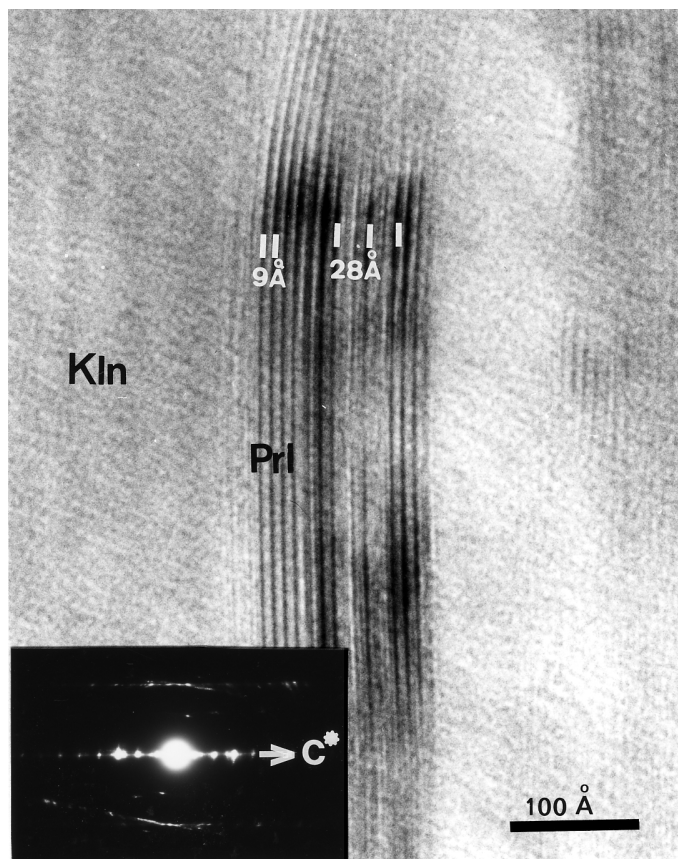

FIG. 10. TEM image showing islands of thin pyrophyllite packets, within the kaolin mineral packet. The pyrophyllite packet also includes $28 \AA$ fringes, corresponding to dickite. Layer termination causes bending of the packet. The SAED pattern (inset) shows the more intense kaolin mineral reflections, with streaking along $c^{*}$, and weaker pyrophyllite reflections. 
the presence of these layers probably contributes to the broadening of the basal reflections of the kaolin mineral, observed in the XRD patterns. These structures also produce streaking of the basal reflections in the SAED pattern (inset in Fig. 10).

\section{DISCUSSION}

Textural relationships among pyrophyllite and the other phases, microstructures in pyrophyllite (e.g. the presence of interstratifications), and chemical data can be used to deduce the following reaction sequence that produced the current paragenesis.

Textural features, as observed by optical microscopy, suggest that the parent material of the pyrophyllite bed was a volcanoclastic rock, containing both primary and detrital clasts. The scarcity or absence of free silica in the present paragenesis and the chemical composition indicate, however, that leaching of the original rock must have been active, and produced a high-alumina rock. Textural relationships suggest a leaching process prior to the metamorphic event, which must have created an aluminous palaeosol protolith. Weathering of acidic to intermediate rocks leads commonly to the development of bauxitic or lateritic soils, under tropical climates (Chamley, 1989a and references therein). These types of rocks have occasionally been interpreted as the parent rocks for pyrophyllite deposits or pyrophyllitebearing rocks (Robert, 1971; Jansen \& Schuiling, 1976; Sharma, 1979; Feenstra, 1985). Weathering of acidic to intermediate rocks under temperatehumid climate would lead, on the other hand, to profiles mainly formed by smectite (Pedro, 1981). Intermediate conditions can produce mixtures of smectite and kaolinite. The $\mathrm{SiO}_{2} / \mathrm{Al}_{2} \mathrm{O}_{3}$ ratio of the pyrophyllite bed closely corresponds to a mixture of $\sim 40 \%$ smectite and $\sim 60 \%$ kaolinite (see Table 2 ). This assemblage would recrystallize into the observed mineralogy during the low-grade metamorphic event. Figure 2 shows the possible path of the bulk-rock composition during the dehydration reactions.

Pyrophyllite shows coherent boundaries with the kaolin mineral, the three crystallographic axes being almost parallel. Islands of pyrophyllite packets within the kaolin mineral packets suggest an homogeneous nucleation of pyrophyllite. Coherent replacement of the kaolin mineral by pyrophyllite also results in the formation of boehmite, which forms complex intergrowths with pyrophyllite. This assemblage, and the absence (or scarcity) of silica suggest that the reaction

$$
2 \mathrm{Kln}=\mathrm{Prl}+2 \mathrm{Bhm}+\mathrm{H}_{2} \mathrm{O}
$$

which occurs at temperatures near $350^{\circ} \mathrm{C}$ (Evans \& Guggenheim, 1991), was the main mechanism for pyrophyllite formation. Nevertheless, the approximate ratio (weight ratio) pyrophyllite:boehmite $(\sim 9: 1)$ deduced from the X-ray patterns is notably higher than that obtained from this reaction $(\sim 4: 1)$. This suggests that pyrophyllite formation could begin through the reaction

$$
\mathrm{Kln}+2 \mathrm{Qtz}=\mathrm{Prl}+\mathrm{H}_{2} \mathrm{O}
$$

which occurs at slightly lower temperatures (Evans \& Guggenheim, 1991). This latter reaction implies, however, either the presence of free silica in the initial assemblage or the liberation of silica from parallel reactions affecting smectite.

Evolution of smectite during burial and very lowgrade metamorphism leads to illite (or muscovite) formation, through a set of intermediate phases consisting of randomly and regularly interstratified illite-smectite. The kinetics of smectite illitization are dependent on a set of physical and chemical factors, such as temperature, pressure (depth of burial), $\mathrm{K}$ content, and time; this reaction would also be favoured in feldspar-bearing rocks. The studied rock does not contain feldspar and it is unlikely that feldspar could survive an intensive weathering process. Nevertheless, smectite illitization can also occur, following the reaction path

$$
\mathrm{Sm}=\mathrm{Ms}+\mathrm{Chl}+\mathrm{SiO}_{2}+\mathrm{H}_{2} \mathrm{O}
$$

which would provide the silica necessary for the pyrophyllite formation by reaction with the kaolin mineral, in a first stage. In deeply buried sequences, complete illitization occurs between 90 and $150^{\circ} \mathrm{C}$ (Chamley, 1989b), whereas at increasing temperatures, illite is gradually replaced by larger crystals of muscovite.

Textural relationships observed by TEM indicate, however, that mica formation probably occurred from both smectite and the kaolin mineral. Thus, the presence of parallel intergrowths of muscovite/ pyrophyllite, where both phases show close crystallographic relationships, pyrophyllite contains abundant mica-layers, and mica packets replace the kaolin mineral (Fig. 11a), indicates that muscovite and pyrophyllite growth was contemporaneous, the formation of pyrophyllite, mica or mixed-layer phases probably being dependent on the $\mathrm{K}+\mathrm{Na}$ 


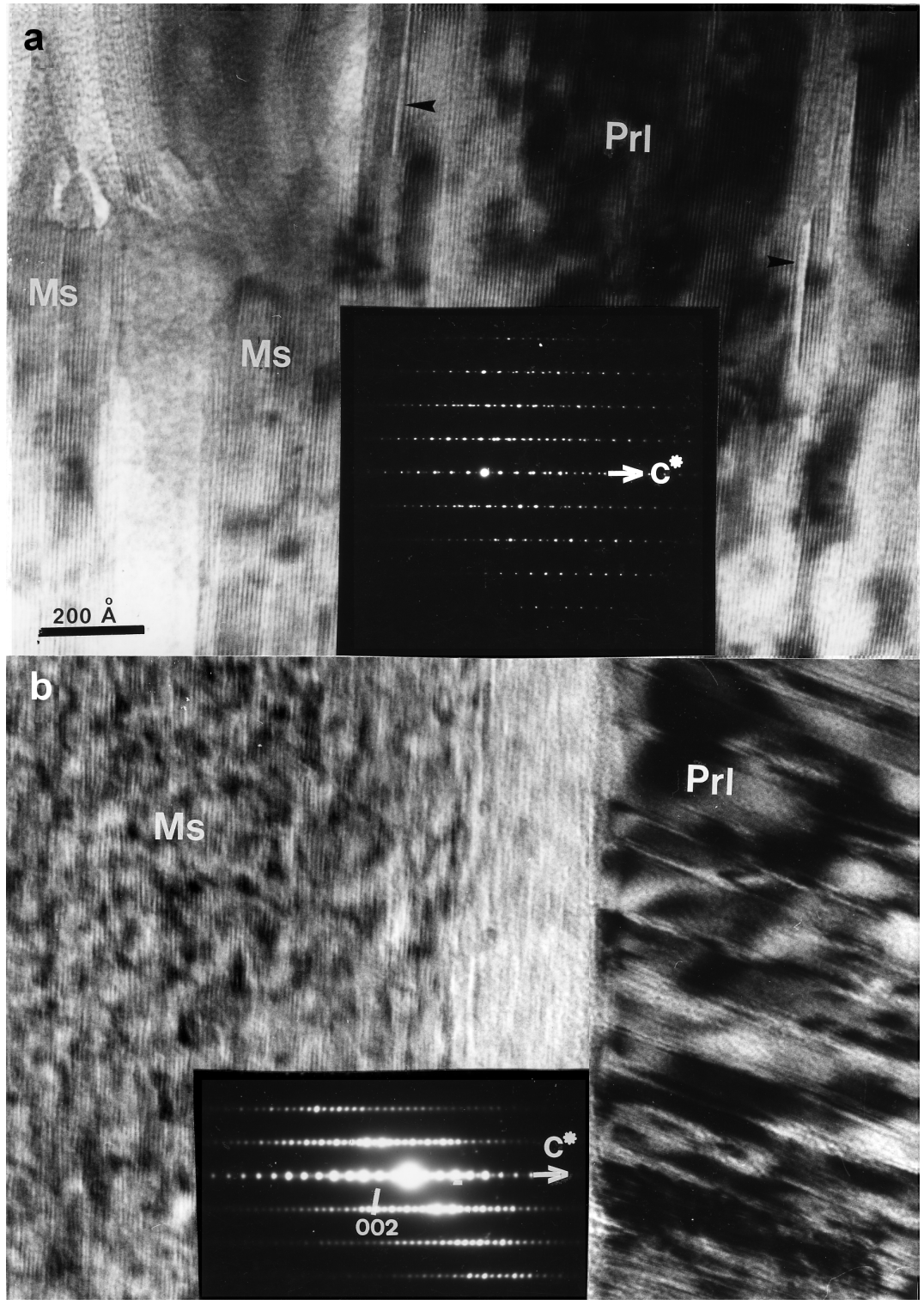

FIG. 11. TEM images showing the textural relations between muscovite and pyrophyllite. (a) Na muscovite and pyrophyllite, formed from the kaolin mineral, maintains close orientation relationships as revealed by the SAED pattern (inset), obtained along [110] of pyrophyllite and muscovite. Arrows mark partial interlayering of muscovite layers within the pyrophyllite packet. The SAED pattern also shows the two-layer structure of the mica. (b) Large Na-free muscovite and pyrophyllite packets, showing an oblique boundary. The SAED pattern of the mica corresponds to a two-layer very ordered polytype. The scale is the same for both parts.

availability in the differing microdomains. Muscovite formation would occur in this case through the reaction

$$
3 \mathrm{Kln}+\mathrm{K}_{2} \mathrm{O}\left(\mathrm{Na}_{2} \mathrm{O}\right)=2 \mathrm{Ms}+4 \mathrm{H}_{2} \mathrm{O}
$$

Kaolinite illitization can occur from $140^{\circ} \mathrm{C}$ in deeply buried rocks (Ehrenberg \& Nadeau, 1989), the extent of the reaction depending mainly on the availability of $\mathrm{K}$. The low $\mathrm{K}$ content in this rock suggests, however, that formation of mica through 
this latter reaction was probably scarce. On the other hand, mica analyses show, in this case, notable $\mathrm{Na}$ content, whereas large mica crystals such as those in Fig. 11b, which show oblique contacts with pyrophyllite, are Na-free. The composition of $\mathrm{Na}-\mathrm{K}$ micas range from $\mathrm{Ms}_{78} \mathrm{Pg}_{22}$ to $\mathrm{Ms}_{60} \mathrm{Pg}_{40}$, and fall within the Ms-Pg solvus defined by Shau et al. (1991). Micas with such intermediate composition are metastable and are generally interpreted as derived from smectite (Li et al., 1994). This suggests that mica formed initially was Na-rich and that incomplete recrystallization in a later stage produced Na-free muscovite. This process, frequently observed in low-grade sequences (Frey, 1987; Jiang \& Peacor, 1993; Merriman \& Peacor, 1999) would also promote the formation of paragonite. The XRD patterns indicate the presence of a small amount of paragonite, which has not been identified, however, by TEM.

The persistence of a kaolin mineral in the observed paragenesis indicates that reactions forming pyrophyllite were not completed, and suggests that the maximum temperature was on the order of $350^{\circ} \mathrm{C}$. Nevertheless, the kaolin mineral might have persisted as a metastable phase at higher temperatures, mainly if pyrophyllite formation occurred through a rapid heating process or under low fluid/rock ratios.

Numerous field data indicate that kaolinite is unstable during burial and low-grade metamorphism, and the transition kaolinite $\rightarrow$ dickite is a well documented process, which occurs over a range of temperatures. Ehrenberg et al. (1993) found that this transition begins at $\sim 140^{\circ} \mathrm{C}$, although in strongly deformed areas, this transition occurs at lower temperatures (Ruiz Cruz \& Reyes, 1998). The presence of dickite layers interstratified with pyrophyllite suggests that the kaolin polytype present in the studied bed is dickite. Unfortunately, it has not been possible to obtain well oriented patterns characteristic of a two-layer polytype.

The lack of equilibrium in the assemblage described is also demonstrated by the presence of boehmite. The phase usually found with pyrophyllite is diaspore. Although the polymorphic relations between boehmite and diaspore are not clear, most of the proposed stability diagrams (Haas \& Holdaway, 1973; Deer et al., 1975a; Day, 1976) indicate that boehmite forms, as a stable or metastable phase, at lower pressure and temperature than diaspore. The presence of boehmite instead of diaspore in this assemblage also indicates that reactions occurred either through a rapid heating process, probably as a consequence of a high thermal gradient related to the emplacement of Jurassic plutonic rocks or under low fluid/rock ratios.

\section{CONCLUDING REMARKS}

The textures, chemistry and mineralogy of the La Ligua pyrophyllite indicate that the leaching and desilicification of a primary volcanoclastic rock, previous to metamorphism, produced a highalumina and low-silica rock, which was the protolith of the pyrophyllite rock. A later, very low-grade metamorphic process produced the observed mineral assemblage at a temperature of $\sim 350^{\circ} \mathrm{C}$. The main reactions leading to the present mineral assemblage included: (1) pyrophyllite+boehmite growth from a kaolin mineral; (2) illitization of the kaolin mineral and smectite; and (3) recrystallization of Na-rich muscovite and formation of Na-poor muscovite and paragonite. The presence of the kaolin mineral, $\mathrm{Na}$ muscovite and boehmite implies a disequilibrium assemblage.

\section{ACKNOWLEDGMENTS}

The authors are grateful to P. Schiffman and F. Nieto, whose corrections and suggestions notably improved the manuscript, and to M.M. Abad for help in obtaining the TEM/AEM data. This work was supported by the Junta de Andalucía Groups RNM-187 and RNM-199 and by the FONDECYT Project 1961108.

\section{REFERENCES}

Aguirre L. (1985) The Southern Andes. Pp. 265-376 in: The Ocean Basins and Margins, v. 7A, The Pacific Ocean (A.E.M. Nairn, F.G. Stehli \& S. Uyeda, editors). Plenum Press, New York.

Bailey S.W. (1984) Structures of layer silicates. Pp. 1-124 in: Crystal Structures of Clay Minerals and their X-ray Identification (G.W. Brindley \& G. Brown, editors.) Monograph 5, Mineralogical Society, London.

Bowers T.S., Jackson K.J. \& Helgeson H.C. (1984) Equilibrium Activity Diagrams for Coexisting Minerals and Aqueous Solutions at Pressures and Temperatures to $5 \mathrm{~kb}$ and $600^{\circ} \mathrm{C}$. Springer-Verlag, New York, 397 pp.

Chamley H. (1989a) Clay formation through weathering. Pp. 3-20 in: Clay Sedimentology (H. 
Chamley, editor). Springer-Verlag, Berlin.

Chamley H. (1989b) Depth of burial. Pp. 359-389 in: Clay Sedimentology (H. Chamley, editor) SpringerVerlag, Berlin.

Charrier R. (1979) El Triásico en Chile y regiones adyacentes de Argentina: una reconstrucción paleogeográfica y paleoclimática. Comunicaciones, 26, $1-37$.

Day H.W. (1976) A working model of some equilibria in the system alumina-silica-water. American Journal of Science, 276, 1254-1284.

Deer W.A., Howie R.A. \& Zussman J. (1975a) Hydroxides. Pp. 89-127 in: Rock Forming Minerals, Vol. 5: Non-silicates. Longman, London.

Deer W.A., Howie R.A. \& Zussman J. (1975b) Montmorillonite group. Pp. 226-245 in: Rock Forming Minerals, Vol. 3: Sheet silicates. Longman, London.

Ehrenberg S.N. \& Nadeau P.H. (1989) Formation of diagenetic illite in sandstones of the Gran Formation, Haltenbauken area, mid-Norwegian continental shelf. Clay Minerals, 24, 233-253.

Ehrenberg S.N., Aagaard P., Wilson M.J., Fraser A.R. \& Duthie D.M.L. (1993) Depth-dependent transformation of kaolinite to dickite in sandstones of the Norwegian continental shelf. Clay Minerals, 28, $325-352$.

Evans B.W. \& Guggenheim S. (1991) Talc, pyrophyllite, and related minerals. Pp. 225-294 in: Hydrous Phyllosilicates (Exclusive of Micas) (S.W. Bailey, editor). Reviews in Mineralogy, 19, Mineralogical Society of America, Washington, D.C.

Feenstra A. (1985) Metamorphism of bauxites on Naxos, Greece. Geologica Unltraiectina, 39, 1-206.

Frey M. (1978) Progressive low-grade metamorphism of a black shale formation, Central Swiss Alps, with special reference to pyrophyllite and margarite bearing assemblages. Journal of Petrology, 19, 95-135.

Frey M. (1987) Very low-grade metamorphism of clastic sedimentary rocks. Pp. 9-58 in: Low-temperature Metamorphism (M. Frey, editor). Blackie, Glasgow.

Haas H. \& Holdaway M.J. (1973) Equilibria in the system $\mathrm{Al}_{2} \mathrm{O}_{3}-\mathrm{SiO}_{2}-\mathrm{H}_{2} \mathrm{O}$ involving the stability limits of pyrophyllite, and thermodynamic data of pyrophyllite. American Journal of Science, 273, 449-464.

Jansen J.B.H. \& Schuiling R.D. (1976) Metamorphism on Naxos: Petrology and geothermal gradient. American Journal of Science, 276, 1225-1253.

Jiang W.-T., Essene E.J. \& Peacor D.R. (1990) Transmission electron microscopic study of coexisting pyrophyllite and muscovite: Direct evidence for the metastability of illite. Clays and Clay Minerals, 38, 225-240.

Jiang W.-T. \& Peacor D.R. (1993) Formation and modification of metastable intermediate sodium potassium mica, paragonite and muscovite in hydrothermally altered metabasites from northern Wales. American Mineralogist, 78, 782-793.

Kodama H. (1958) Mineralogical study on some pyrophyllites in Japan. Mineralogical Journal, 2, 236-244.

Kretz R. (1983) Symbols for rock-forming minerals. American Mineralogist, 68, 277-279.

Levi B., Aguirre L., Padilla H. \& Vergara M. (1989) Low-grade regional metamorphism in the MesozoicCenozoic volcanic sequences of the Central Andes. Journal of Metamorphic Geology, 7, 487-495.

Li G., Peacor D.R., Merriman R.J. \& Roberts B. (1994) The diagenetic to low-grade metamorphic evolution of matrix white micas in the system muscoviteparagonite in a mudrock from central Wales, United Kingdom. Clays and Clay Minerals, 42, 369-381.

Lorimer G.W. \& Cliff G. (1976) Analytical electron microscopy of minerals. Pp. 506-519 in: Electron Microscopy in Mineralogy (H.R. Wenk, editor). Springer-Verlag, New York.

Merriman R.J. \& Peacor D.R. (1999) Very low-grade metapelites: Mineralogy, microfabrics and measuring reactions progress. Pp. 10-60 in: Low-grade Metamorphism (M. Frey \& D. Robinson, editors). Blackwell Science, Oxford.

Montoya J.W. \& Hemley J.J. (1975) Activity relations and stabilities in alkali feldspar and mica alteration reactions. Economic Geology, 70, 577-583.

Norrish K. \& Hutton J.T. (1969) An accurate X-ray spectrographic method for the analysis of a wide range of geological materials. Geochimica et Cosmochimica Acta, 33, 431-453.

Oyarzún M., Aguirre L. \& Morata D. (1997) Quimismo bimodal y metamorfismo de bajo grado en las rocas volcánicas triásicas de la cordillera de la Costa de Chile central. $8^{\circ}$ Congreso Geológico Chileno, Antofagasta, Actas, vol. 2, 1424-1428.

Page R.H. (1980) Partial interlayers in phyllosilicates studied by TEM. Contributions to Mineralogy and Petrology, 75, 309-314.

Pedro G. (1981) Les grands traits de l'évolution cristallochimique des minéraux au cour de l'altération superficielle des roches. Rendiconti della Società Italiana di Mineralogia e Petrologia, 37, 633-666.

Robert P. (1971) Sur un gisement de bauxite de l'île d'Eube (Grece). Comptes Rendus de l'Academie de Sciences de Paris, 272-26, 3228-3230.

Reynolds R.C. (1991) Mixed-layer chlorite minerals. Pp. 601-674 in: Hydrous Phyllosilicates (Exclusive of Micas) (S.W. Bailey, editor). Reviews in Mineralogy, 19, Mineralogical Society of America, Washington, D.C.

Rivano S., Sepúlveda R., Boric R. \& Espiñeira D. (1993) Mapa geológico de las Hojas Quillota y Portillo. Servicio Nacional de Geología y Minería. Mapas 
Geológicos, Nº73, escala 1:250.000, Santiago.

Robinson D., Bevins R.E., Aguirre L. \& Vergara M. (2004) A reappraisal of episodic burial metamorphism in the Andes of central Chile. Contributions to Mineralogy and Petrology, 146, 513-528.

Ruiz Cruz M.D. \& Reyes E. (1998) Kaolinite and dickite formation during shale diagenesis: isotopic data. Applied Geochemistry, 13, 95-104.

Ruiz Cruz M.D., Puga E., Aguirre L., Vergara M. \& Morata D. (2002) Vermiculite-like minerals in lowgrade metasediments from the Coastal Range of central Chile. Clay Minerals, 37, 221-234.

Schultz L.G. (1964) Quantitative interpretation of mineralogical data for Pierre Shale. US Geological Survey Professional Paper, 391-C, 31 pp.

Sharma R.P. (1979) Origin of the pyrophyllite-diaspore deposits of the Bundelkhand Complex, central India.
Mineral Deposita, 14, 343-352.

Shau Y.-H., Feather M.E., Essene E.J. \& Peacor D.R. (1991) Genesis and solvus relations of submicroscopically intergrown paragonite and phengite in blueschists from northern California. Contributions to Mineralogy and Petrology, 106, 367-378.

Thomas H. (1958) Geología de la Cordillera de la Costa entre el valle de La Ligua y la Cuesta de Barriga. Instituto de Investigaciones Geológicas, 2, 86 p.

Vergara M., Levi B., Nyström J.O. \& Cancino A. (1995) Jurassic and Early Cretaceous island arc volcanism, extension, and subsidence in the Coast Range of central Chile. Geological Society of America Bulletin, 107, 1427-1440.

Zen E. (1961) Mineralogy and petrology of the system $\mathrm{Al}_{2} \mathrm{O}_{3}-\mathrm{SiO}_{2}-\mathrm{H}_{2} \mathrm{O}$ in some pyrophyllite deposits of North Carolina. American Mineralogist, 46, 52-66. 